\title{
CLIMATE MAPPING AND URBAN PLANNING: TECHNICAL AND COMMUNITY READING IN CÁCERES-MT
}

\author{
Ana Carolina Vicentim Batista Ribeiro ${ }^{1}$, João Carlos Machado Sanches ${ }^{1}$, Renata Mansuelo \\ Alves Domingos ${ }^{2}$, Emeli Lalesca Aparecida da Guarda ${ }^{3}$, Erika Fernanda Toledo Borges ${ }^{1}$ \\ ${ }^{1}$ Department of Civil Engineering, Mato Grosso State University, Sinop, Mato Grosso, Brazil \\ ${ }^{2}$ Department of Civil Engineering, Federal University of Santa Catarina, Brazil \\ ${ }^{3}$ Department of Architecture and Urbanism, Federal University of Santa Catarina, Brazil
}

Received 24 September 2020; received in revised form 10 November 2020; accepted 23 December 2020

\begin{abstract}
Due to the accelerated urbanization process, Brazilian cities grow with little or no urban planning, and when it is present, climate issues are generally not considered, especially in small and medium-sized cities. Thus, the present research had as objective to evaluate a method of application of climatic knowledge throughout the process of revision of the Municipal Master Plan of Cáceres-MT. The methodology used to evaluate climatic variables is based on data provided by INMET and mobile transect measurements within the urban perimeter. Through this, it was possible to know the behavior of air temperature, relative humidity, precipitation, wind speed and direction during the dry season and also over the years. Thus, through mobile transect measurements, a temperature difference between the analyzed points of $1.2^{\circ} \mathrm{C}$ in the morning period and $1,9^{\circ} \mathrm{C}$ in the afternoon and evening periods could be observed. As for humidity, a difference of $10 \%$ was observed in the morning period and $9 \%$ in the afternoon and evening periods. Therefore, through the phases of the Master Plan (diagnosis, prognosis and public management), proposals have been prepared to mitigate the identified harmful effects of the most affected areas in relation to the climate, and thus, contribute to the review process of the Municipal Master Plan of Cáceres-MT with climatic knowledge.
\end{abstract}

Keywords: Urban planning; Climate change; Master plan

(C) 2020 Journal of Urban and Environmental Engineering (JUEE). All rights reserved. 


\section{INTRODUCTION}

With the disorderly growth of urban agglomerations, which occurred mainly from the middle of the twentieth century in Brazil, the relationship between man and nature is becoming increasingly complex. Human action has been producing impacts on the natural environment causing a low quality of life, related to changes in local climates.

Assis (2005) states that at the local and mesoclimatic level, the built environment must be studied in detail, as it tends to significantly alter the natural climate. Grimmond et al. (2010) demonstrates that climate change occurs due to the urbanization process. These changes in the urban environment cause adverse effects on human health due to thermal discomfort caused by rising temperatures and decreasing relative humidity, which often form heat islands and produce poor wind distribution.

On July 10, 2001, Law 10.257, called the City Statute, was approved and, according to it, urban studies and environmental aspects for urban quality should contribute to the elaboration of the Master Plans. Thus, there is a need for climate knowledge that can support this process, including tools and information easily accessible and assimilated for those involved with urban planning.

In this context, the municipality of Cáceres, Mato Grosso State, is currently reviewing its Master Plan in a present situation of environmental fragility. Cáceres, a medium sized city (IBGE, 2017), has a perimeter that encompasses almost the entire urbanized area. The occupation is very diffuse, with large amount of urban voids and low population density. It is also noted that there was no concern in relating the urban climate with the urban planning of the municipality.

Given this, the need arises to obtain climate knowledge and thus insert the issues related to climate within the urban planning of the city of Cáceres in the revision of the Municipal Master Plan and its complementary laws. According to Assis (2003, p.145), if there is climate information, it must be included in the planning and management of cities, by the so-called climate responsible urban planning.

Thus, this research aims to evaluate a method of application of climate knowledge throughout the participatory process of revision of the Municipal Master Plan of Cáceres-MT, from the diagnosis stage to the elaboration of proposals, through the mapping of climate variables as temperature, relative humidity, precipitation, wind speed and direction within the municipality, also analysing the influence of land use and occupation on these variables.

\section{URBAN CLIMATE}

It is notorious that urban spaces and human activities are directly related to the urban climate. Urban areas influence air quality, temperature, precipitation and wind patterns, significantly changing the climatic factors of a locality (GHENO, 2013). The studies of climate change and urban climate are not equal in all territorial extension, since in each region there are distinct urbanization processes. The State of Mato Grosso, for example, began to receive a high migratory flow in the second half of the 1960s and it was during this period that there was a growing occupation of its urban area due to the significant migratory flow to this region. (VENDRAMINI et al., 2016).

Thus, Oke (apud BESERRA FILHO, 2015) points out that the denser region, with greater activity and movement, which is usually the central part of cities, has a higher temperature than residential and peripheral neighbourhoods, this fact characterizes the phenomenon of heat islands. Sanches (2015) states that the heat island effect in cities occurs due to reduced evaporation, increased roughness, thermal properties of buildings and paved surfaces. Thus, it can be analysed that when studying about heat islands should be considered not only the climatic characteristics of the local environment, but also the topographic conditions in which it is inserted, the social characteristics and human behavior, since it is directly related to the influence on the urban climate.

\section{Urban Climate in Mato Grosso}

The beginning of studies on the urban climate in Mato Grosso occurred in the 1990s, conducted by Maitelli et al. (1991) whose purpose was to investigate and locate in the city of Cuiabá the possible occurrence of heat islands, in order to subsidize the Master Plan of this municipality. Zamparoni (1995), in the interior of the state, carried out her studies in small towns, such as Tangará da Serra and Barra do Bugres, where she analyzed the differences in temperature and relative humidity from heat islands derived from urban land use. Sette (1996) studied the climate of the city of Rondonópolis, southern region of the state, seeking to understand the effects of urbanization on air temperature, humidity and rainfall.

Sanches (2015) analyzed Sinop-MT climate variables and evaluated a methodology for the insertion of climate issues as a criterion for urban planning in small and medium-sized cities. These climate analysis studies in cities aim to improve environmental conditions and conduct urban planning actions, such as Municipal Master Plans. 


\section{Spatial and climatic characteristics of Cáceres-MT}

The object of study is the city of Cáceres, located in the state of Mato Grosso, latitude $16^{\circ} 04$ '14' 'S and longitude $57^{\circ} 40^{\prime} 44^{\prime \prime} \mathrm{W}$, considered medium size (IBGE 2017), with 91,271 inhabitants, and density 3.61 inhabitants / $\mathrm{km}^{2}$ (IBGE, 2010). It was founded in 1778 and is located at the point of confluence between the Paraguay River and the BR-070, BR-174 and BR-364 highways in the Alto Pantanal microregion, a sub-region of the Pantanal biome. It is characterized by savannahs without periodic flooding, flooded fields and aquatic environments such as freshwater lagoons and rivers.

Mato Grosso is contained in the Intertropical Zone, below the equator and above the tropic of Capricorn. For this reason, it has a high temperature during much of the year and there is little difference between seasons. According to the climate classification proposed by the Mato Grosso socioeconomic-ecological zoning (Moreno \& Higa, 2005), the climate of Mato Grosso is classified as Tropical climate, but it is divided into two units according to temperature and rainfall characteristics: I Continental equatorial climate with defined dry season (3 to 5 months); and II - Alternately humid and dry continental tropical climate.

According to this classification, Cáceres belongs to group II, subunit II-A. Corresponds to depressions and plains with altitudes between 95 and 200 meters, where the climate can be classified as tropical megathermal sub-humid. In this subunit, there is a clear decrease in total rainfall $(1200$ and $1500 \mathrm{~mm})$. Annual average temperatures range from $25{ }^{\circ} \mathrm{C}$ to $26^{\circ} \mathrm{C}$, while highs often exceed $35^{\circ} \mathrm{C}$ throughout most of the year, and the dry period extends from April-May to SeptemberOctober in general.

\section{Evaluation methods of urban climate}

\section{Mobile transect}

The empirical method using mobile transects has been widespread since the late 1920s. This is widely used because it is simple to apply, has lower cost compared to other methods and also because of the reliability of the evaluation of climatic parameters (PERSSON apud SOUZA and ASSIS, 2007).

This method clearly shows the differences in the urban environment, using as many collection points as possible, distributed in the study environment. It also has greater agility in the monitoring process, as well as the possibility of making measurements at different times of the year (FIALHO, 2009). Thus, Sanches (2015) uses the mobile transect method to obtain climatic variables of air temperature and relative humidity for the purposes of climate analysis.

\section{Kriging geoestatistes method}

Due to the greatness of a territorial space in the execution of the research and due to the lack of equipment, it is difficult to carry out measurements through the mobile transect at very close points. Thus, geostatistical methods, based on interpolation, are relevant in correcting the data to obtain the realities of the climatic conditions of a given space (ZÁRATE et al., 2008).

Kriging is a geostatistical process that, unlike other interpolation methods, estimates values of variables distributed through a spatial covariance matrix that defines the weights assigned to different samples, the treatment of data redundancy, the neighbourhood to be considered in the inferential procedure and the error associated with the estimated value. Using the semivariogram in its modelling, can be compared with the traditional methods of estimation by weighted averages or by moving averages. However, the fundamental difference is that only kriging presents unbiased estimates and the minimum variance associated with the estimated value. (Siqueira et al., 2012; Weber \& Englund, 1994).

Although there are several methods by Kriging, the one that best meet the needs is ordinary Kriging, this method is more used, due to the simplicity and results it provides. It is a local method of estimation and, therefore, estimation at an unsampled point results from the linear combination of the values found in the immediate neighbourhood. This method was recently used successfully for the same type of study by Candido (2017) and Trindade (2016).

\section{Insertion of environmental issues in urban planning through the Master Plan}

Willheim (1979) states that the objective of urbanism is to carefully analyze the reality of the scope of urban life and, based on this analysis, to propose and implement change strategies. These strategies must be able to induce and lead to change in the proposed reality. Thus, according to the 1998 Constitution, the master plan became a mandatory instrument for municipalities with more than 20 thousand inhabitants and must be approved by the City Council, after participatory discussion with the population and different sectors of society.

According to the Federal Constitution (art. 182, § 1), the Master Plan consists of the basic instrument of urban development and expansion policy, which must respect the following principles: guarantee of the right to sustainable cities; city development planning; ordering and controlling land use; integration and complementarity between urban and rural activities; 
protection, preservation and recovery of the built and natural environment, in addition to the democratic management of the city, through the participation of the population.

Therefore, for the revision of the Municipal Master Plan of Cáceres, the city made an agreement with the University of the State of Mato Grosso - UNEMAT, since the absence of the revision of the Master Plan puts the municipal mayor in the sights of Law 8,429, of June 2, 1992, the Administrative Improbity Law, for incurring an improbity act, as provided for in item VII of article 52 of the City Statute. In this way, the technical team responsible for the work is made up of $\mathrm{PhD}$ professors from UNEMAT, academics and technicians from the most diverse areas of the municipal government, who are responsible for raising all issues that involve the city, in its positive and negative aspects.

For the implementation stages of the master plan to be well structured, Moreira et al. (2005) proposes the division of the in-depth study as follows: diagnosis, prognosis, proposals and management. When completed, these steps should seek to modify the present reality in order to obtain a better quality of life for the population.

\section{Diagnosis}

The diagnosis consists of the analysis of a situation that makes up the scenario of the existing reality. Therefore, it consists of the collection and organization of data on a given geographical area and a given subject. Usually the diagnosis is divided into five axes, namely: socioeconomic, environmental, land use and occupation, infrastructure and mobility and circulation. In this stage, three procedures are carried out in order to identify which are the conditions, potentialities and deficiencies of the region. (FRANCO, 2001).

In this work, the environmental axis will be more commonly addressed. The analysis of environmental planning in the Master Plans shows that although the incorporation of environmental issues in the Plans has expanded, few municipalities adhere to mechanisms and instruments capable of carrying out environmental policy. (SANCHES, 2015).

\section{Prognosis}

After the stage of diagnosis that is characterized by knowing the study environment safely, the prognosis can be defined with a question: "Considering the current situation of the city, if nothing is done, what will this city be like tomorrow?" (FRANCO, 2001). Also according to this author, this process determines how the city will behave in the next 5,10 , or 20 years if no preventive and planning measures are taken.

\section{Proposals}

The proposals start from the result of an urban planning process and they are what transform a foreseeable future into a possible future. Thus, considering the elaboration of proposals in relation to the environmental axis, Romero (2011) expresses that a bioclimatically adequate urban legislation, should bring guidelines for the most significant variables of the urban environment, many of which depend on issues related to space management. As an example, the importance of preventing heated air masses from being transported over areas of concentration of inhabitants, which can occur from the location of high traffic routes.

\section{Urban Management}

Duarte (2011) states that if there is an urban plan as a result of a planning process, it is up to the urban management to make it happen effectively and as planned. According to the City Statute, article $40 \S 3$ and 4 is the role of management to promote the revision of the law that institutes the Master Plan, at least, every ten years. In the process of preparing the Master Plan and in monitoring its implementation, the Legislative and Executive Powers will guarantee the population the promotion of public hearings and debates with the participation of the population, in addition to ensuring publicity and access to any interested party the documents and information produced.,

\section{METHODOLOGY}

\section{Urban Climate Assessment}

The methodology of this project is based on data made available by the National Meteorological Institute (INMET) for the analysis of climatic variables over the years. And also, in empirical methods to obtain climatic variables (temperature and relative humidity) due to the availability of equipment. In addition, it uses numerical methods for processing the collected data.

The urban land use and occupation map of the Cáreces urban perimeter is divided into green areas, urban voids, institutional areas, residential use and commercial use. These described uses were demarcated on the map from aerial images made available by Google Earth and the Google Street View tool, in addition to carrying out routes by car on the streets of Cáceres-MT, in order to manually record each type of use of the ground on the urban perimeter map, which was divided by blocks. Subsequently, the AutoCAD software was used to mark each land use on the map in different colours. Through the land use and occupation map, the map of urban forms of Cáceres was obtained. 
This last map is divided into 5 categories considering developed urban areas, suburban areas, areas of varied use, semi-rural areas and areas of permanent protection and reserves.

\section{Determinations of Climate Variables}

The climatic analyses of the city of Cáceres were divided into two stages, namely the determination of temperature, relative humidity, precipitation, wind speed and direction from an INMET fixed station located in the municipality. The second stage was characterized using field measurements by mobile transect to obtain temperature and relative humidity data in the most consolidated urban perimeter of the city under study.

\section{INMET Fixed Station}

From the information obtained by the automatic station of INMET - National Institute of Meteorology installed in the city of Cáceres, located in the military reserve, it was possible to verify the evolution of temperature, relative humidity, precipitation, speed and wind direction between the years 1972 and 2017, which made it possible to analyze the behavior of climatic conditions over the 44-year period.

The data obtained by the station were stored in Microsoft Excel spreadsheets in order to contribute and facilitate the analysis. For the analysis of the wind direction in the city of Cáceres, the data were stored in Microsoft Excel spreadsheets, then processed in the WRPLOT View Freeware 8.0.0 software. After entering the data in the WRPLOT software, the frequency of the wind direction is analysed in the electronic spreadsheet and the vector resulting from the predominant wind direction in the dry and rainy periods of the region is obtained.

\section{Field measurements by mobile transect}

The methodology used to determine the climatic variables of temperature and relative humidity in the dry season by mobile transect was based on the doctoral thesis of Sanches (2015) and Candido (2017).

For mobile measurements it was necessary to use a set of sensors, model ITWH-1080 from Instrutemp, with a temperature accuracy of $\pm 1^{\circ} \mathrm{C}$, a measuring range of $40{ }^{\circ} \mathrm{C}$ to $65^{\circ} \mathrm{C}$ and a precision for humidity of $\pm 5 \%$, a measurement range from $10 \%$ to $99 \%$ (INSTRUTEMP, 2010). The sensor capable of detecting the temperature and humidity of the environment was mounted inside a protection against solar radiation, in order to minimize impact on the readings.
This set is attached to the roof of the car, with a height of $1.5 \mathrm{~m}$ through a metallic support, after the assembly totals a height of $2.2 \mathrm{~m}$, which is close to the heights recommended by the authors, which range between 0.75 and 2, 0 meters (ACHBERGER \& BA, 1999; ASSIS et al., 2007; HEUSINKVELD et al., 2014; HÄB et al., 2015; LIU et al., 2016). A console was also used, which during the measurement period is inside the vehicle, making it possible to view the station's meteorological data. These data were recorded manually and later transferred to an electronic spreadsheet, in order to avoid errors at the time of measurement. The methodology proposed by Sanches (2015) defines the transect points based on the degree of impact on the formation of urban microclimates, according to urbanized areas.

The route of the points of transects, Fig. 1, was carried out in 15 points of a more consolidated area of the city of Cáceres, passing through intense traffic routes and through characteristic areas, representing different patterns of land use and occupation, such as commerce, residence and mixed areas. The route was selected so that the measurement time would take around an hour. Although Cáceres does not have an orthogonal urban grid, the points were distributed in the most uniform possible way related to distance. In choosing these points, we sought to highlight the influence of the reserve areas, such as the army reserve and the city's construction density.

After defining the 15 points for the route of the mobile transect, measurements began in the dry period on three consecutive working days, which were performed on Wednesday, Thursday and Friday in September $2017(08 / 30 / 2017$ to 01/09/2017), at the following times $08: 00 \mathrm{~h}, 14: 00 \mathrm{~h}$ and $20: 00 \mathrm{~h}$, with the measurements lasting one hour (1:00h).

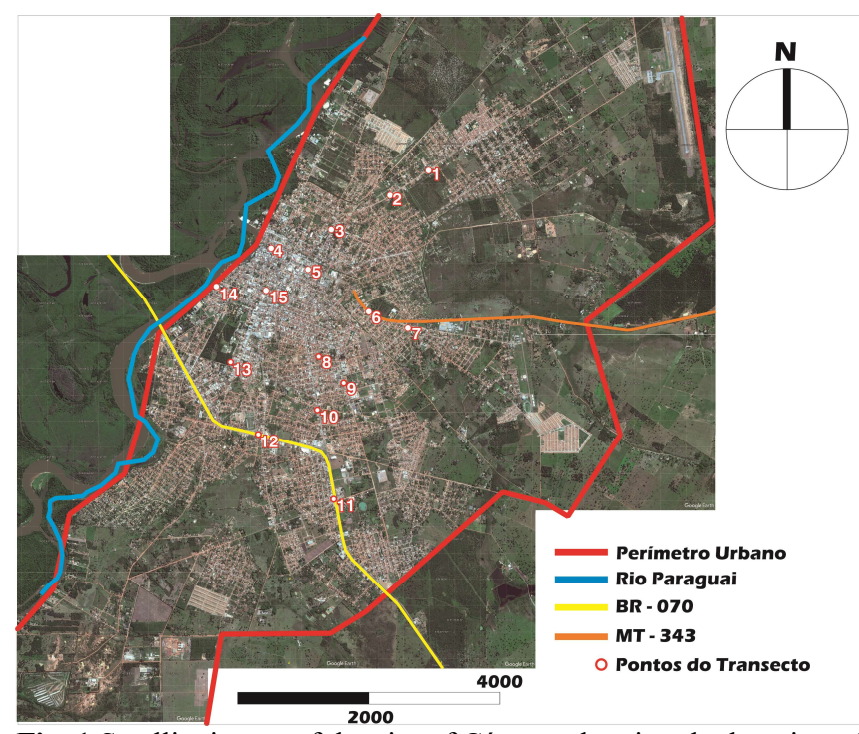

Fig. 1 Satellite image of the city of Cáceres showing the location of the survey measurement points (PDM Diagnosis of Cáceres, 2017) 
The times were determined according to Sanches (2015), in which each time interval represents respectively the period after sunrise (morning), the warmest (afternoon) and the period after sunset (night). Therefore, at the established times and with the equipment attached to the car, measurements started at the first point.

According to Sanches et al. (2017), when traveling, the car must not exceed the speed of $40 \mathrm{~km} / \mathrm{h}$ and must remain at least two minutes at each measurement point in order to stabilize and observe the data receiving signal that appears on the console. The data recorded in this step were temperature and relative humidity, as well as noting the exact minute when these were recorded.

In order to validate the data obtained after covering the 15 points, it was returned to point 1 and recorded the temperature, relative humidity and the exact time of the annotation that would later undergo correction processes. The data collected during the drought period made it possible to analyze the behavior of climatic conditions, such as temperature and humidity during this period, showing the influence of the urban organization.

The data obtained in the measurements by mobile transect were stored in electronic spreadsheets and subsequently went through corrections due to the lack of a fixed station that recorded from minute to minute in order to compare the data.

Thus, Souza and Assis (2007, p.3) state that if the path has the same start and end point, linear data correction can be performed in a simplified way, "simply by uniformly distributing the difference between the temperatures measured in the beginning and end of the route by the number of points. After the correction, the temperatures measured at the beginning and at the end of the route will be the same". This method was used to correct the temperature and relative humidity data, since with the completion of the route, one returned to the starting point.

Subsequently, maps were generated using the kriging method, using SAGA GIS geostatistics software, in which the corrected temperature and relative humidity averages of the three days of measurements in each period were inserted. Thus, temperature and humidity distribution maps were obtained separately for the three morning, afternoon and night periods.

From these maps, the most heated areas and the highest concentration of urban activities were identified according to the climatic changes of each region in the dry season.

\section{Climate Analysis}

Through the climatic analysis, it was possible to highlight areas with relevant climatic changes in the urban environment, due to the land use map of the city of Cáceres, superimposed on the temperature and relative humidity distribution maps, elaborated with the average values obtained from these variables and from the knowledge of the wind regime, previously exposed.

Using the SAGA GIS software, three regions were obtained regarding the highest values of air temperature in the three measurement periods, and three regions characterized by lower values of relative air humidity found in the morning, afternoon and night, totaling six regions.

According to Sanches (2015), the grouping of these formed regions, goes through a process of overlap, where these overlaps are divided to later form new regions that highlight the temperatures and the relative humidity of the air considering the climatic changes in the drought period. In this way, it is possible to generate a map of areas with climatic changes in the dry season.

The climate analysis map of the city under study was made from the overlay of the classification maps of urban structures with a tendency to affect the climate (Map of urban forms) and the map of areas with climate change. The classifications indicated in the climate analysis map were made considering, in addition to the areas that contribute to the regulation and easing of the rigors of the local climate, the areas that present greater changes in relation to the climate, such as denser regions. From the Climate Analysis Map, it was possible to draw guidelines for the elaboration of intervention proposals, in order to mitigate the harmful effects recorded from the climatic variables.

\section{Climate recommendations}

Based on the principle of Barandier (2013) apud Sanches (2015), it is possible to relate the problems found in the environmental plan with urban planning instruments. In this work, the problems found in Cáceres-MT were considered, and the Master Plan was defined as a municipal instrument of urban planning to characterize the insertion of climate issues, since through the review of the Master Plan it is possible to observe the need for environmental conservation policies. (BARANDIER, 2013 apud SANCHES, 2015)

The revision of a city's Master Plan and its complementary laws must be based on the principles established by the City Statute. These principles are based on the stages of diagnosis, prognosis, proposals and participatory management, which can be carried out with adults and children, which was the case in Cáceres.

Thus, one of the principles is the formation of a technical team responsible for the work, formed essentially by technicians from the most diverse areas of the municipal government in order to have a community management. Moreira et al. (2005) states that these 
technicians should participate in meetings, forums or seminars that will take place during the elaboration or review of the plan so that later important decisions are discussed democratically with the population.

Therefore, the PDM team from Cáceres held on $12 / 07 / 2017$ a meeting with technicians from the City Hall, in order to present the diagnosis material and listen to the reservations of each one to obtain better performances in the production of the Master Plan.

On March 14, 2018, a training workshop took place in which several municipal departments participated in order to discuss the use and occupation of the city under study. After the presentations, the material produced was made available to everyone through the Cáceres City Hall website.

Another principle that must be followed in the preparation/review of the Master Plan is participatory democracy, in which there is a need for community participation in the preparation of proposals, as guaranteed by the population's right in art. 2nd of the City Statute.

Community workshops were held with adults and children in order to understand the needs of the residents of this municipality and, from there, develop effective guidelines that contribute to the environmental planning of the city. In this stage, the partnership with the city hall was of paramount importance, since the education department made available all the necessary information about the city's schools to conduct community workshops.

\section{Proposals}

Based on the steps carried out in the review of the Master Plan of Cáceres-MT, being diagnostic, prognostic and participative management, and considering the reality in which Cáceres is inserted, proposals were created from an environmental point of view that will serve as a basis for the future of draft laws.

Therefore, in this work, bioclimatic proposals should be presented considering the climatic variables of the urban environment, through the review of the PDMC. These proposals aim to solve the problems found in the short and long term diagnosis, related to the urban perimeter of Cáceres-MT, density, land use, urban expansion and environmental changes.

\section{RESULTS}

\section{Diagnosis and Land use}

The map of urban forms (Fig. 2), generated from the land use and occupation map, shows a concentration of commercial establishments in the historic center of the city, along the axes of Avenues Talhamares, Gen. Osório, Padre Casemiro, 7 de Setembro and Tancredo Neves. On the margins of the BR - 070 highway, larger businesses and services are concentrated, such as car wholesalers and resellers (area 1). It is noticed, however, that there is a diffusion of shops and services throughout all neighbourhoods, with mixed use, commerce and residence in the same lot being quite frequent. These mixed areas are considered to be suburban with medium development (area 2). The areas of institutional use, characterized by wide spaces (area 3 ), such as schools, hospitals, airports, hospitals and universities are distributed within the entire urban perimeter of the city.

It is important to highlight the large unoccupied areas within the urban perimeter, considered semi-rural (area 4), in the peripheral regions, but also in the central areas and in the oldest neighborhoods in the city. In addition, in the furthest areas are the permanent preservation areas (area 5), with few reserves in the central part of the city.

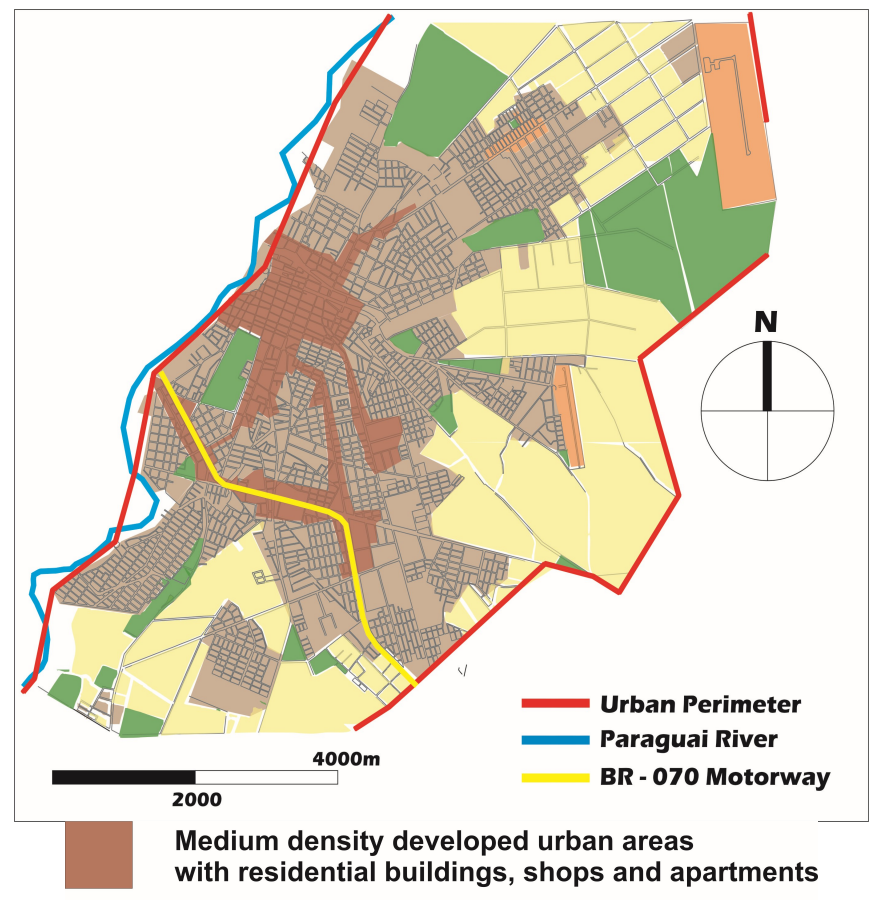

\begin{abstract}
Suburban areas with medium development and low density, with residential buildings of 1 to 2 floors.

Areas of varied use, with large buildings in wide spaces, such as universities, hospitals and airports.
\end{abstract}

Semi-rural areas with buildings scattered over natural or agricultural areas.

Permanent protection areas and forest reserves.

Fig. 2 Map of the urban forms of the city of Cáceres. 
Data analysis based on information obtained by the INMET automatic station

The data obtained by the INMET automatic station, installed in the city of Cáceres, indicated the monthly average temperature, between the years 1972 - 2017.

The lowest temperatures were observed in the months of June and July (around $23^{\circ} \mathrm{C}$ ), due to the cold fronts active in this period. The highest average temperatures are recorded in the months of October and November, the beginning of the rainy season. The highest monthly average temperature recorded by INMET was in October with $27.4^{\circ} \mathrm{C}$, and the lowest in July with 22.5 ${ }^{\circ} \mathrm{C}$.

The average annual temperature from the years 1972 to 2017 was also analysed. It can be seen that there is a tendency for the temperature to rise, around $1.5^{\circ} \mathrm{C}$ over the years analyzed, justified by the increase in impermeable areas, increased density population and increased traffic of motor vehicles in this period. In addition, it was observed that in the years 2001 and 2012 the average annual temperature was higher than 27 ${ }^{\circ} \mathrm{C}$, surpassing the domains of the climatic subunit in which Cáceres is inserted.

For the characterization of the relative humidity of the air, the monthly average of the temperatures in the registered years was made. The highest average relative air humidity was recorded in the months from January to March, the peak of the rainy season, with $82 \%$, the lowest in the month of August, with 64\%.

There is a reduction in the average annual humidity, since there is a decrease in green areas and an increase in the surface runoff of the water, contributing to the decrease in the relative humidity of the air over the years. This is a sharp decrease, varying from around $80 \%$ to around $71 \%$ in those 44 years evaluated.

Another variable analyzed was the average monthly rainfall in the same period. There was a low rainfall in the months of June, July and August, with $19.22 \mathrm{~mm}$, $15.12 \mathrm{~mm}$ and $15.88 \mathrm{~mm}$, respectively. The highest rainfall in the studied period occurred in the months of January and December, with an average monthly rainfall of $239.49 \mathrm{~mm}$ and $206.10 \mathrm{~mm}$.

As for the average annual precipitation, the highest rainfall was registered in 1972 with $151.23 \mathrm{~mm}$ and the lowest in 1981 with $68.53 \mathrm{~mm}$. An average precipitation of approximately $104 \mathrm{~mm}$ was obtained in the entire period already recorded in Cáceres, without any trend of increasing or decreasing this variable over the years.

When analysing the monthly wind speed between the years 1972 and 2017, it was possible to record the months of February and March with speeds of $1.01 \mathrm{~m} / \mathrm{s}$ and $0.98 \mathrm{~m} / \mathrm{s}$, respectively, these being the lowest average speeds obtained among the months. The month of September stands out for having the highest wind speed in the studied period, with an average speed of $1.40 \mathrm{~m} / \mathrm{s}$.

At the average annual speed, there is an increase, going from around $0.8 \mathrm{~m} / \mathrm{s}$ in 1972, to approximately $1.6 \mathrm{~m} / \mathrm{s}$ in 2017 , due to deforestation caused by the horizontal expansion of the city and the agricultural occupation of its surroundings. The wind tends to reach the city with greater speed, without encountering plant barriers. The average wind speed in Cáceres in the entire period studied is $1.17 \mathrm{~m} / \mathrm{s}$.

Finally, for the characterization of the winds, wind rose was generated from the WRPLOT, using all data provided by INMET. It was observed, on average, that the predominant direction of the prevailing winds (Figure 3) is North Northeast (NNE) with an average speed of $1.35 \mathrm{~m} / \mathrm{s}$.

Therefore, in addition to the low speed recorded, the winds reach the city parallel to the Paraguay River, that is, without carrying moisture from the river. For the rainy season, we have a predominant wind in the Northeast (NE) direction, with a speed of $1.39 \mathrm{~m} / \mathrm{s}$. The wind rose for the dry season has a predominant wind direction in the North $(\mathrm{N})$ and a speed of $1.33 \mathrm{~m} / \mathrm{s}$.

\section{Measurements from the points of the mobile transect}

In the morning, the climatic conditions were favorable to measurements with the presence of dry and hot air masses, only on $9 / 1 / 2017$ it was cloudy in the first 15 min of measurement. Thus, it was registered that point 9, located at Av. Getúlio Vargas, had the highest temperature at $26.6^{\circ} \mathrm{C}$, while point 14 , located near the Paraguay River, had the lowest temperature in this measurement period with $25.8^{\circ} \mathrm{C}$.

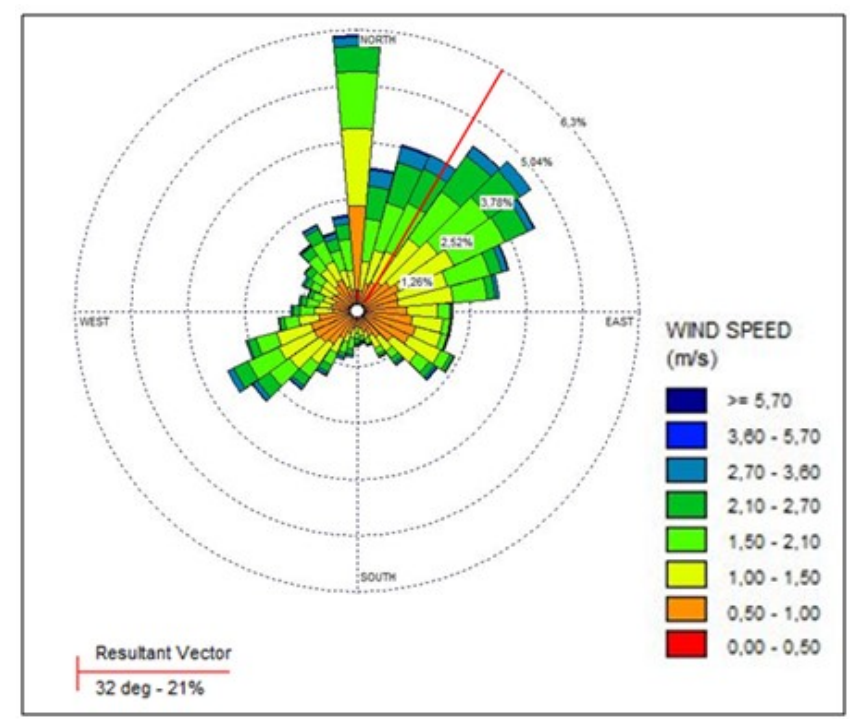

Fig. 3 Wind rose from every period (PDM Diagnosis of Cáceres, 2017) 
The influence of land use and occupation on the temperature is noticed, since point 9 is characterized by the maximum average temperature in the morning, and is located in a region of intense traffic of vehicles and people, in addition to having a high constructive density, with hospital, residences and shops. The point considered to have the lowest temperature (point 14), is located next to the Paraguay River and close to the military plant reserve, thus demonstrating the influence of water bodies and vegetation on decreasing temperatures in the city. The biggest temperature difference between the measurement days was between points 9 and 15 recorded on 08/30/2017 with a variation of $1.2{ }^{\circ} \mathrm{C}$, being considered significant for the morning period, since the city is starting the radiation absorption process. In the characterization of the relative humidity of the air, in the morning period in the city of Cáceres, an opposite behaviour was observed to that of the temperature, since in point 9 it was registered, on average, a lower value of relative humidity, of $64 \%$. The maximum relative humidity was obtained at point 14 , next to the Paraguay River, with $69 \%$, which also coincides with the lowest temperature in the morning.

For this measurement period, the largest difference in relative humidity between the points was recorded on $08 / 30 / 2017$, with a variation of $10 \%$, with the highest humidity recorded on that day being found in point 14 (59\%) and the lowest at point 11 (49\%). Points 14 and 15, located near the Paraguay River, registered the highest relative humidity in the air, however, it is clear that this water resource influences humidification only in the points close to it. As seen earlier, the prevailing wind direction does not favour the dispersion of river moisture throughout the city. By observing the temperature and relative humidity distribution maps of the morning period (Fig. 4 and Fig. 5), we can see a region with higher temperatures in the central part of the city of Cáceres, including Avenida 7 de Setembro and Praça Barão, located in the historic center, which are represented by points 4 and 5, respectively.

As for humidity, a low air humidity was recorded at these same points, since they are areas with high construction density and the soil is completely waterproofed and predominantly commercial, in addition to having intense vehicle and pedestrian traffic. In the distribution maps below, opaque parts in a single color should be disregarded, as they are regions distant from the interpolation points and do not represent reality. In the afternoon, the measurements recorded maximum averages at different points in the previous period, as the city undergoes maximum absorption of solar radiation. Therefore, the maximum average temperature recorded is found at point $5\left(37.2^{\circ} \mathrm{C}\right)$, located at Av. 7 de Setembro, in the central part of the city.

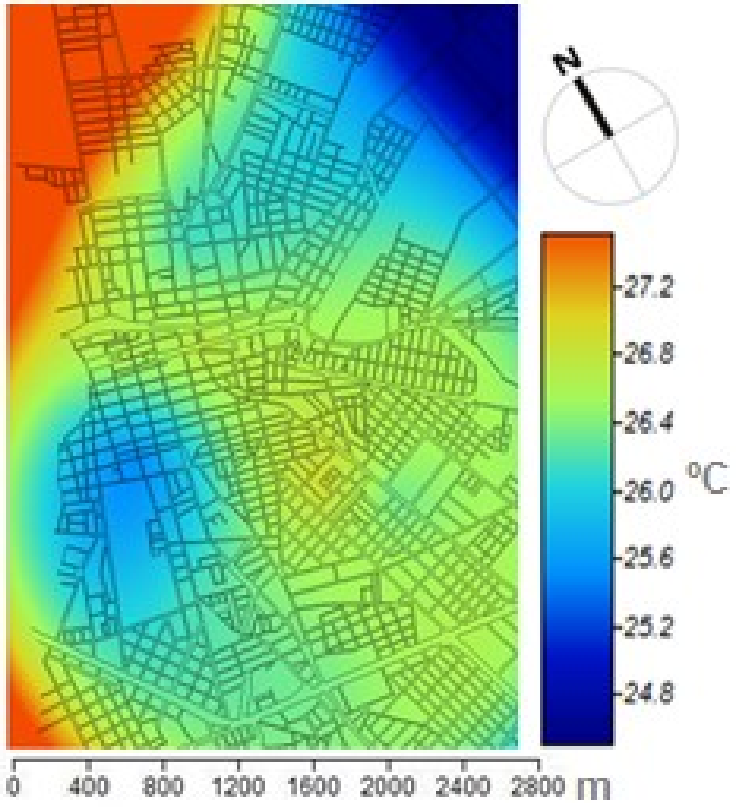

Fig. 4 Wind rose from every period (PDM Diagnosis of Cáceres, 2017)

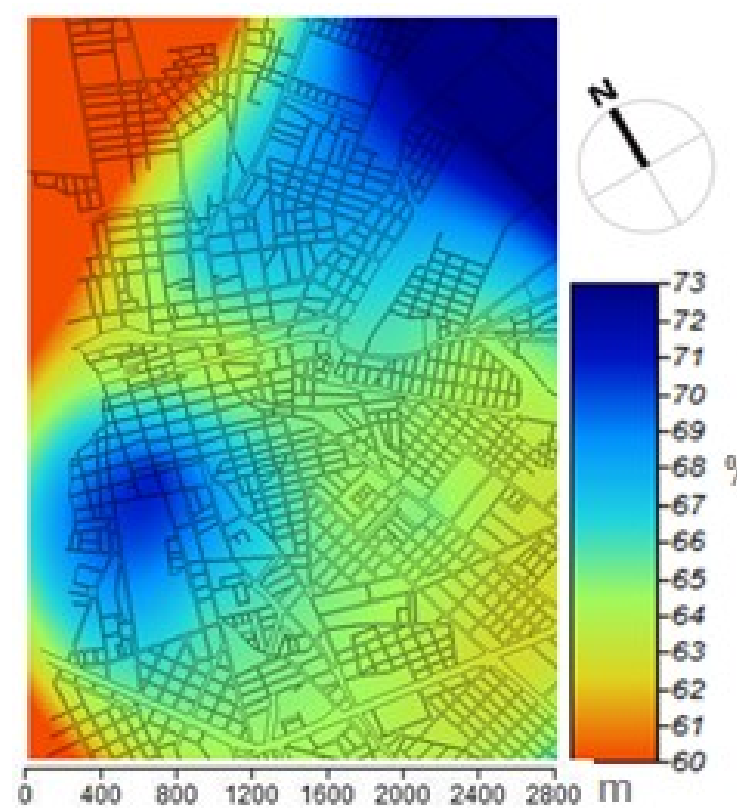

Fig. 5 Map of distribution of relative humidity (\%) in the morning.

(PDM Diagnosis of Cáceres, 2017)

This increase in temperature can be justified due to the intense flow of motor vehicles and pedestrians in this region, as it is a predominantly commercial area, in addition to the presence of schools and hospitals nearby. Points 14 and 15, located near the Paraguay River, registered the lowest average temperature of $35.8^{\circ} \mathrm{C}$, thus demonstrating the influence of water resources on temperature. On $08 / 30 / 2017$, the greatest temperature variation was observed between the points of maximum average temperature (point $5,39.6^{\circ} \mathrm{C}$ ) and minimum 
average temperature (point $15,37.8^{\circ} \mathrm{C}$ ), this difference being $1.9^{\circ} \mathrm{C}$.

For humidity measurements in this afternoon period, the inverse temperature behaviour remained, thus characterizing a lower relative humidity at the highest temperature point. In this case, point 6 recorded, on average, the lowest relative humidity of the air with $28 \%$, not being the point with the lowest temperature. However, it is close to the lowest temperature point, point 5 with $29 \%$ and has similar land use and occupation. The point of greatest relative humidity of the air remained at point $15(35 \%)$, due to the presence of the Paraguay River in this region.

The higher relative humidity difference between the points found in this period measurements was on 09.01.2017, with a 9\% variation between the point with the highest relative humidity recorded $(35 \%)$ and lower humidity $(26 \%)$, these coinciding with the lowest and highest temperature recorded in that period, respectively.

The distribution maps of the temperature and relative humidity of the air, for the evening period (Fig. 6 and Fig. 7), show that the regions with lower temperature and higher relative humidity are found in areas close to the Paraguay River, thus obtaining influence from this resource at points near it. It is also noted that it is a predominantly residential area, with some shops, which is also influenced by the vegetation present in the military reserve. In the points with maximum average temperature and lowest relative humidity of the air, a predominantly commercial area is observed, with an intense flow of vehicles and pedestrians, as they are in an area with a hospital and schools nearby. It has low presence of vegetation, and the roads are impermeable, contributing to the increase in temperature in this region.

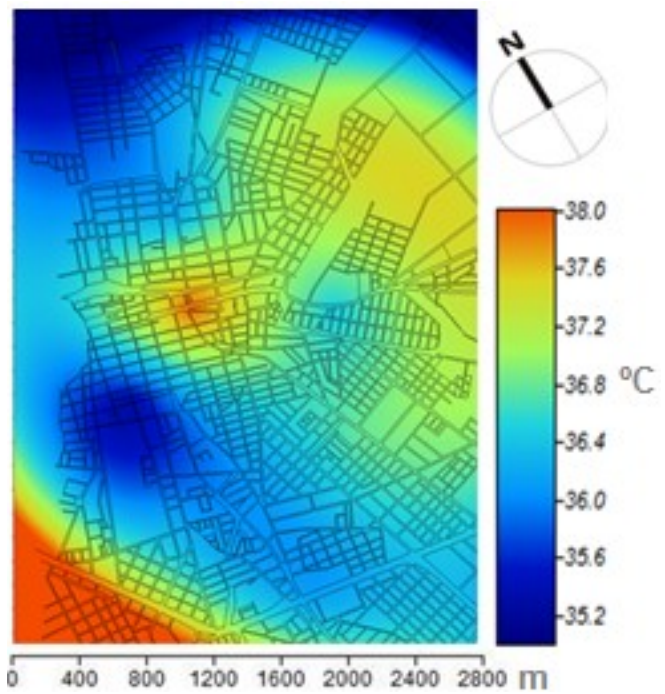

Fig. 6 Air temperature distribution map $\left({ }^{\circ} \mathrm{C}\right)$ in the afternoon. (PDM Diagnosis of Cáceres, 2017)

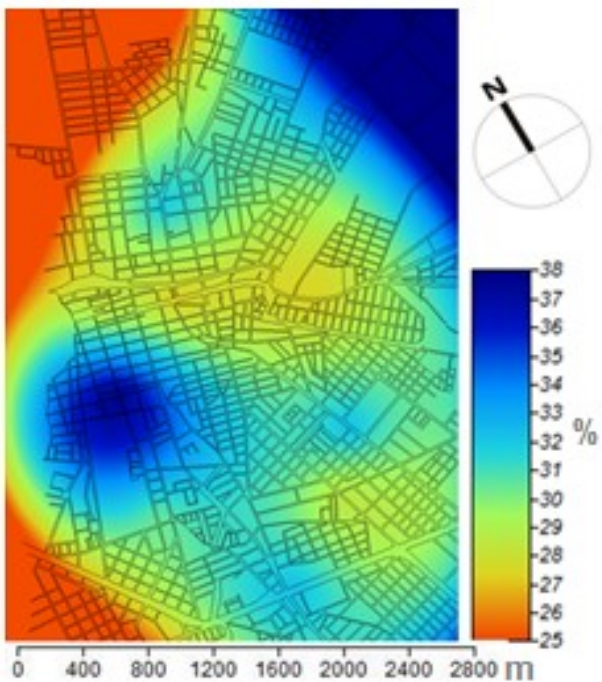

Fig. 7 Distribution map of relative air humidity (\%) in the afternoon (PDM Diagnosis of Cáceres, 2017)

At night, it was recorded, on average, that points 2 and 3, located at Av. São João, had the lowest temperature records at $30.1^{\circ} \mathrm{C}$, while point 5 , located at Av. 7 de September continued to have the highest temperature recorded, with $31.1^{\circ} \mathrm{C}$. The maximum variation found in this measurement period was on 09/01/2017 when point 5 had the highest temperature of $31.4 \%$ and points 2 and 3 had the lowest temperature of $29.5^{\circ} \mathrm{C}$, registering a variation of $1.9^{\circ} \mathrm{C}$. On 01.09.2017 there was the greatest variation of relative humidity between 5 and 15 points $46 \%$ and $57 \%$ respectively, a variation of $9 \%$ relative humidity inside of Caceres.

Regarding the measurements made for relative humidity, it was observed, on average, that the maximum humidity remained at point 15 , close to the Paraguay River, with $52 \%$, coinciding with the lowest temperature recorded. Minimal relative humidity was found at point 5, located at Av. 7 de Setembro, with $48 \%$. The maps of temperature distribution and relative humidity of the air, for the night period (Fig. 8 and Fig. 9), show that the region with the highest temperature records is in the central part of the city. Predominantly commercial areas, with schools and hospitals nearby, contributing to the intensification of the flow of motor vehicles and pedestrians, thus raising the temperature and, consequently, lowering the relative humidity of the air. On these measurement days, the minimum average temperature was recorded at points different from the other periods analysed. These are points 2 and 3, located at Av. São João, close to the State University of Mato Grosso (UNEMAT), a predominantly residential area, with some shops nearby. It has no asphalt pavement, contributing to rapid heat dissipation. The maximum recorded relative humidity, on the other hand, coincided with the other periods, making point 15 , next to the Paraguay River, the most humid region. 


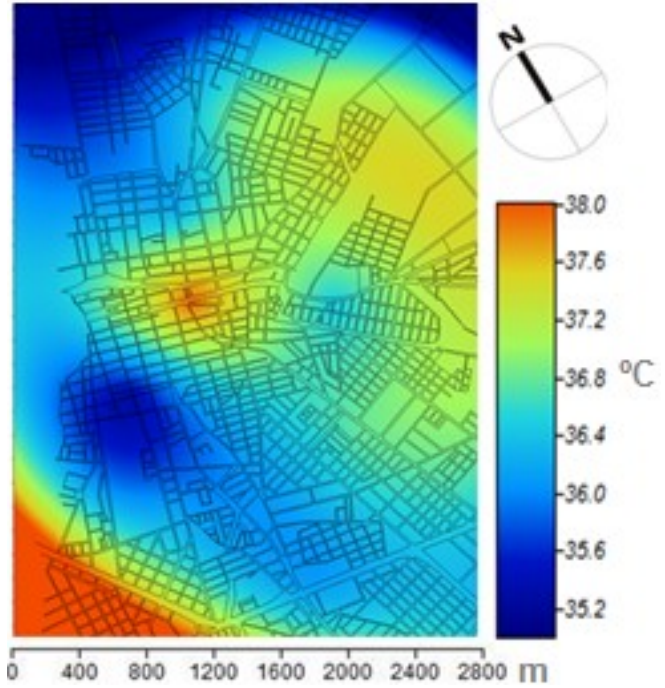

Fig. 8 Air temperature distribution map $\left({ }^{\circ} \mathrm{C}\right)$ in the night. (PDM Diagnosis of Cáceres, 2017)

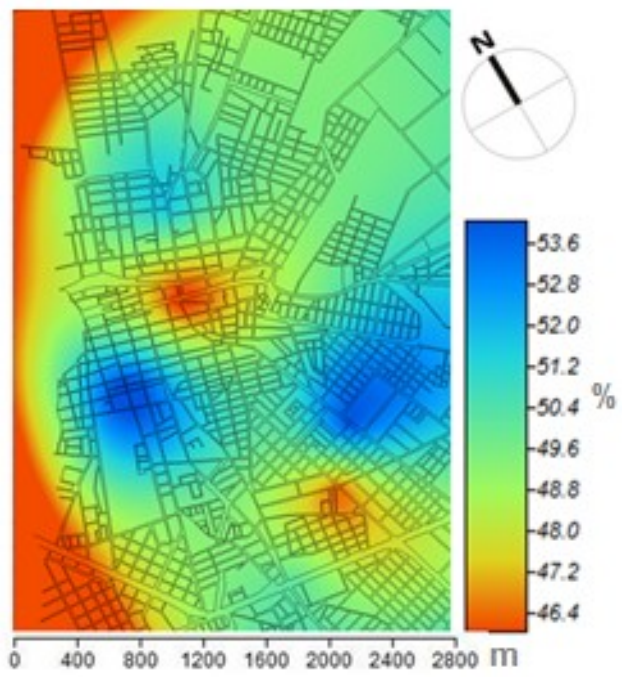

Fig. 9 Map of distribution of relative air humidity (\%) at night. (PDM Diagnosis of Cáceres, 2017)

\section{Participative Management}

The participatory management of the Cáceres Master Plan was consolidated with the presentation of the material produced in the diagnosis on 12/07/2017 in the city of Cáceres. In this presentation meeting, in addition to the members of the PDMC, technicians and secretaries from the City Hall of the city under study were also present. On March 14, 2018, there was a training workshop, Fig. 10, in which several municipal departments participated in order to discuss the use and occupation of the city under study. At this meeting, the technical members were able to make their reservations about the current situation of the municipality. After the presentation meeting, the diagnosis produced by the Municipal Master Plan team was made available on a link on the website of the Municipal Government of Cáceres and disseminated on the city's radio stations so that the entire population had access.

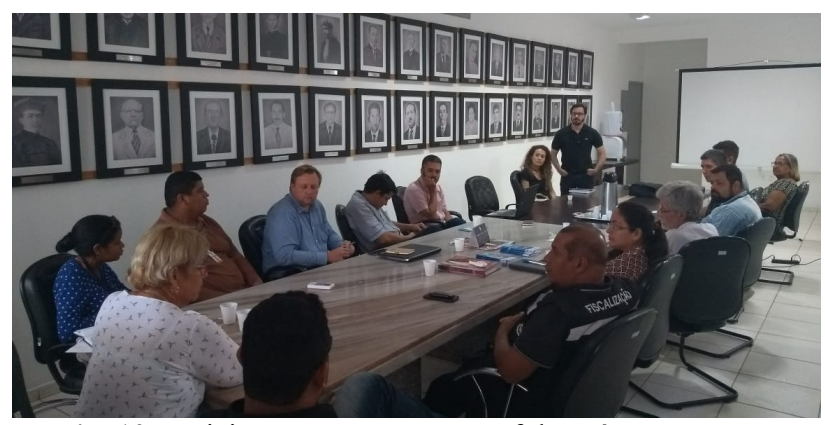

Fig. 10 Participatory Management of the Cáceres Master. (PDMC Team, 2018)

\section{Community workshops}

First, community workshops with children took place, being divided into community workshops I, II and III. Community Workshop I took place with children at Isabel Campos, Raquel Ramão and Tancredo Neves schools, on three consecutive days in March. Considering that the municipality is located in the Pantanal, the activity carried out with the participation of children from the 3rd year was "The animals of Cáceres and Pantanal".

After the students drew the animals they knew, it was observed that the animals most cited in the three schools evaluated, which are concentrated in different urban regions, were the jaguar and later the anaconda, followed by the fish. The children have a wide knowledge about the animals of the Pantanal, since they had no difficulties in classifying and drawing them.

At Tancredo Neves school, some children drew animals that had not been mentioned in any other school, such as iguana, lizard, agouti and emu. Therefore, there was a diversification of knowledge regarding animals in the Pantanal in each school where the activity was proposed. In community workshop II (Fig. 11), which took place simultaneously with workshops I and III, students were asked to show through the drawings where the leisure areas are and which activities they most often play. During the performance of the activities, some difficulties that the children's families had to access the city centre were identified, this is due to the distance from the neighbourhoods where they live, as well as the difficulty of urban mobility that meets this need. In the results presented, it is observed that the places of leisure where they play on a daily basis and weekends are: in the street where they live, in the backyard and in the neighbourhood football field. Leisure activities in urban facilities such as playgrounds and school courts were listed in less than $10 \%$ of the total.

In the community workshop III, the 5th year students of the three schools, Isabel Campos, Raquel Ramão and Tancredo Neves were able to develop drawing activities that represented actions that were detrimental to the environment in the region (Fig. 12). 


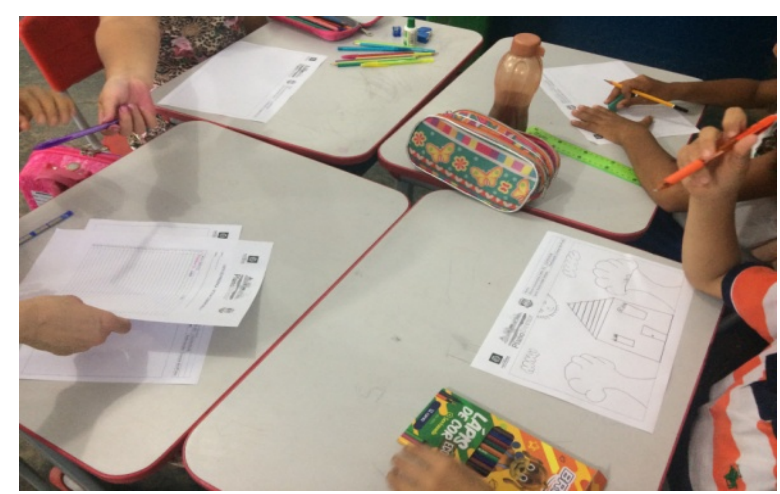

Fig. 11 Community Workshop II, Isabel Campos School (PDMC Team, 2018)

From the results, it is observed that the actions most recognized by the children were forest fires, garbage in the river and deforestation, respectively. Of the actions mentioned, the fires were the majority in the three different urban regions evaluated. The actions of the aforementioned fires were also seen in neighbouring yards, empty fields and accumulated waste. The same consistency in the sequence occurred for the actions of garbage in the river and deforestation. The other shares mentioned do not comprise more than $10 \%$ of the total, although all have been mentioned. The action of depositing/accumulating garbage on the street was often mentioned at the Tancredo Neves School in relation to the others. However, this was the main environmental complaint in the region of the Isabel Campos School, by adult students and the community in general. Complaints were generated both by the lack of collection and by the lack of control / inspection of vacant lots.

At the adults' workshop, in the debate group related to environmental issues (Fig. 13), several points were raised randomly by the participants, who chose the theme of spontaneous will during the workshop. The material prepared with maps and technical language was not very accessible to the population. Thus, we opted for a more spontaneous chat methodology, with open topics and the choice of the participants.

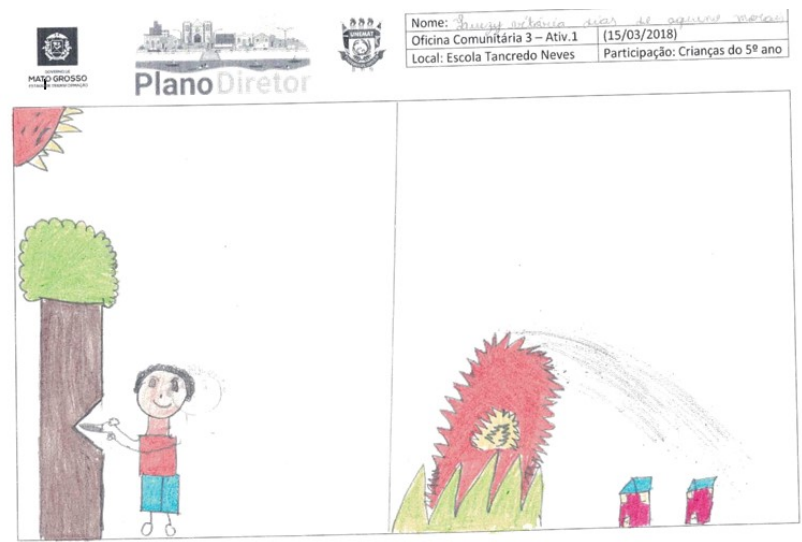

Fig. 12 Community Workshop III, drawing on environmental degradation, Tancredo Neves School (PDMC Team, 2018)

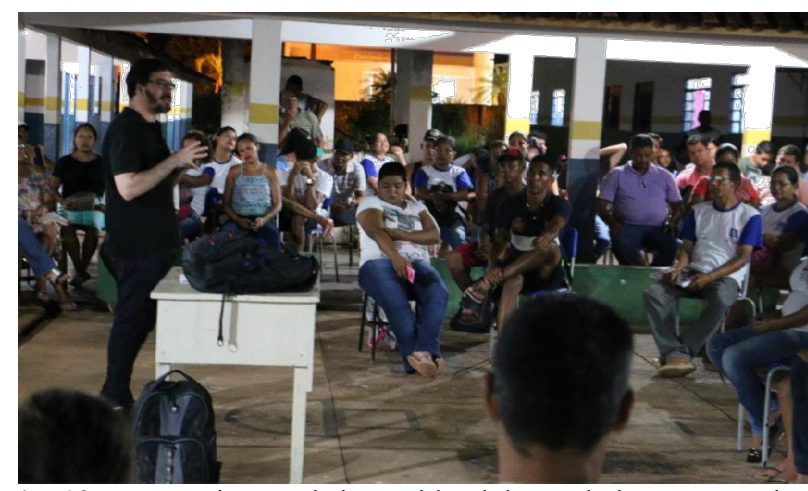

Fig. 13 Community Workshop with adults, Isabel Campos School (PDMC Team, 2018)

In summary, the most listed topic was primarily the issue of river pollution, which directly affects riverside dwellers and their fishing activities, as well as all tourism activity in the city. Second, the issue of garbage and the collection system, with many complaints. The garbage collection system is only accessible where piped water is available, as the payment of the garbage fee with the water bill is foreseen. The lack of inspection of garbage in vacant and abandoned lands was also very present. Finally, the lack of green areas and the emission of pollutants such as forest fires and traffic noise was also mentioned.

The inhabitants heard showed that they perceive, due to the questions previously exposed, that the central area is hotter and drier than the other areas. They also complained about the lack of road afforestation, urban parks and leisure areas in general. They mention that leisure is often done in farms around the city, close to the mountains, in places like Garcez and Julião, with poor access. They also comment that they depend a lot on traveling by individual motor vehicles, abandoning the use of bicycles. They report the absence of public transportation, bike lanes and safety on the routes. Due to the large number of urban voids, the distances to be overcome are very large, passing through regions with poor public lighting, which also prevents the use of bicycles.

\section{Prognosis}

\section{Urban Perimeter}

Through the map of land use and occupation and the urban perimeter of the city of Cáceres-MT, it appears that the current Urban Perimeter is very large, totalling an area of 8,219.14 ha, including the expansion area. It is analysed that the occupation of the municipality is quite diffuse, since there are subdivisions close to the limits of the Urban Perimeter, these being very distant from the central region of the city, contributing to the increase of voids near the most consolidated urban areas. 
Thus, it is observed that almost all urbanized areas of the municipal headquarters are within the Urban Perimeter, with the expansion area being little occupied, demonstrating that the municipality's perimeter of expansion is not necessary. In addition, within the current urban perimeter, there are areas with good conditions for urbanization and which already have all the urban infrastructure and services provided by the city. Considering that nothing will be done by the city, several occurrences can be harmful to the municipality, such as the appearance of new subdivisions in areas far from the regions with better infrastructure, which will consequently result in the increase in the costs of public services. Another factor that may occur is the segregation of the areas furthest from the central region of the city and also the increase in real estate speculation in the municipality of Cáceres, as the city ends up having to expand, leading populations with less resources to live more and more far away, while there are unused properties in more central regions.

One of the concerns with the urban perimeter is the impossibility of offering urban services for the most distant subdivisions, which may occupy areas that must be preserved from an environmental point of view, causing an increase in environmental impacts such as water pollution and air quality.

\section{Density}

Cáceres has a very low population density, with approximately 11.26 inhabitants/ha, this is due to the spread of the urbanized area and the little verticalization found in the municipality. However, the city has urban voids (Fig. 14) in areas with a good supply of infrastructure and close to the main centralities of the city. In addition, it is a city in which there are no geotechnical restrictions on the verticalization of buildings as it has good soil support conditions.

If the low density of the municipality is maintained, some problems can be caused, such as the increase in urban services, considering that the city must take services such as urban cleaning, public lighting, garbage collection to the most remote neighbourhoods. There may also be an increase in the cost of implementing urban infrastructure, since the new subdivisions must have drinking water, electricity, telephone, road network, in addition to other factors that enable mobility and the basic conditions of people living in these new neighbourhoods.

\section{Land Use}

Cáceres has a diffuse occupation and with low population density. Within the current Urban Perimeter, there are regions of the city with commerce and services

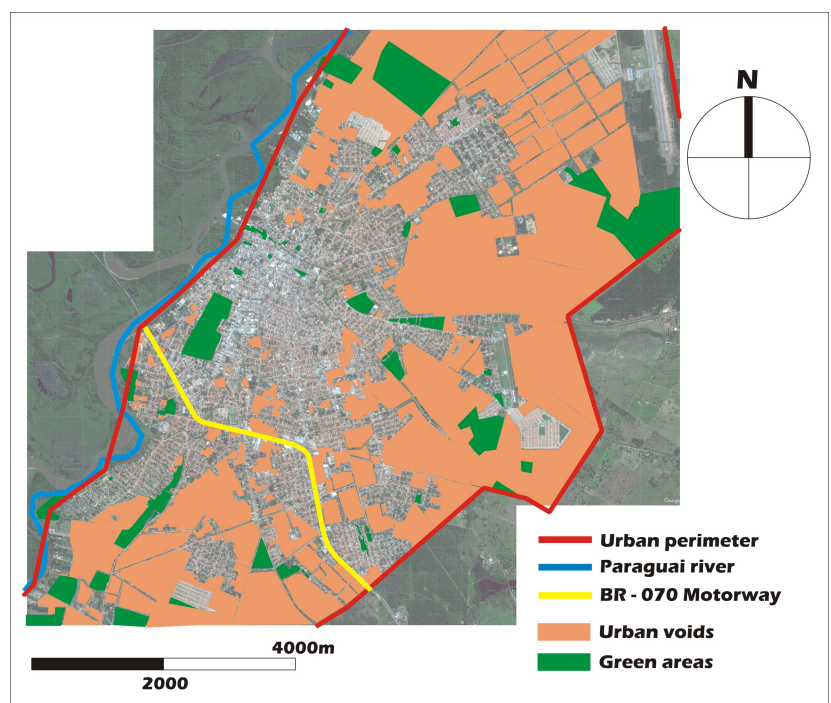

Fig. 14 Indication map of urban voids in the urban perimeter of Cáceres-MT.

(PDMC Prognosis, 2018)

still incipient, depending on the most central areas. In the central part, including the historic center of the municipality, are concentrated the main businesses and services in the region, such as banks, hospitals, schools, supermarkets and stores.

Thus, based on land use and occupation, it is possible to observe that there is a predominance of mixed use, residential and commercial areas, throughout the urban perimeter of the city, however this occurs in different degrees. It is also observed that there are centralities being formed in regions far from the centre, such as the concentration of larger businesses and services on the margins of the BR-070 highway. In relation to public facilities, such as the city hall, secretaries, hospitals, universities and schools, these institutional uses are distributed throughout the city, covering almost the entire population.

With the concentration of shops in the central part of the city, there is an increase in the flow of people and vehicles towards this region, making traffic increasingly intense and chaotic. In addition, excessive energy expenditures can occur on commuting, considering that the population of distant neighbourhoods has to travel to the centre to work and buy.

Therefore, the environmental, economic and social unsustainability of the municipality is seen as a consequence of this centralization, since real estate speculation can occur in areas with better offer of services and infrastructure, causing the increase in the price of urban land.

\section{Urban Expansion}

Cáceres has been expanding radiocentrically, from the original centre, without proper planning, leaving many 
road nodes. For example, the BR 070 highway has limited the expansion of the city in the south direction, but there are already subdivisions in this direction, causing difficulties in crossing the BR due to the intense flow of vehicles.

There are also some developments in the municipality that have functioned as centers of attraction for remote regions (Fig. 15), such as the Residential Lot Dom Máximo (1), in the North of the Center, the Jardim Aeroporto (2), in the North Northeast, the Airport itself, in the same direction (3), the UNEMAT University City (4), which is to the East, the social housing subdivision located next to the University City, in the Lobo region (5), and the allotment of social interest in the region of Vila Real (6) south of the city center, thus showing the growth in all axes of Cáceres.

\section{Environmental changes}

From measurements and analysis of the climatic conditions of Cáceres, it is possible to observe significant changes in climatological variables over time, such as air temperature, relative humidity, precipitation, speed and wind direction. The changes analysed within the urban perimeter were about $+1.5^{\circ}$ $\mathrm{C}$ in temperature, $-8 \%$ humidity, $+0.6 \mathrm{~m} / \mathrm{s}$ wind speed. It was found on the map in Fig. 16 that the most compromised region is concentrated in the city center, from Praça Barão to Avenida 7 de Setembro, encompassing an area of commercial concentration and services with intense traffic of vehicles and people. Thus, there is a tendency to expand these changes along the axes formed by Avenidas Talhamares and Getúlio Vargas, due to the intense urban activity verified and the influence of the prevailing winds.

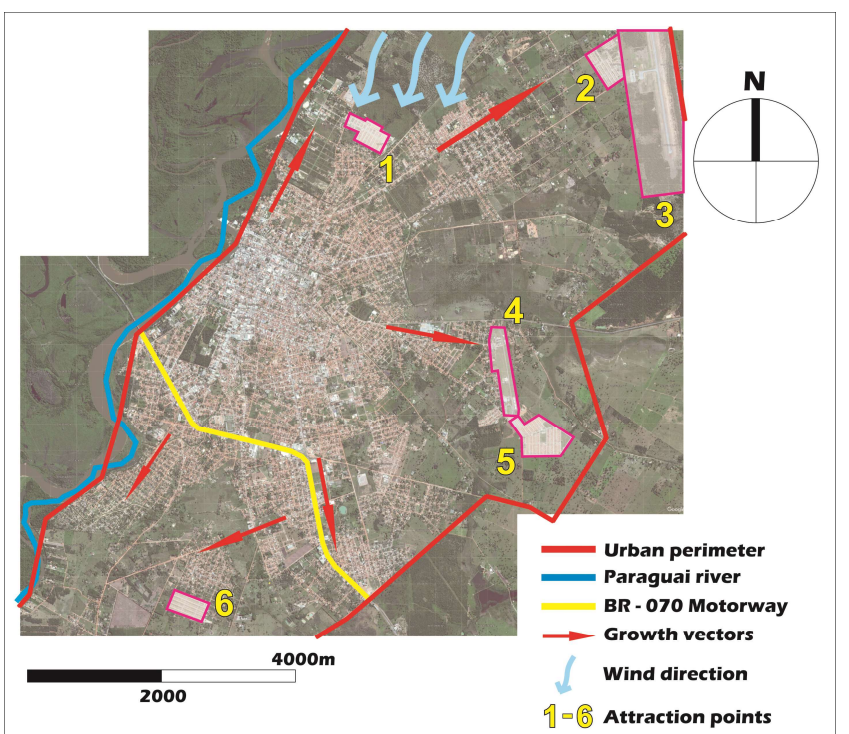

Fig. 15 Map of urban expansion of Cáceres-MT. (PDMC Prognosis, 2018)
In order to improve the environmental and climatic conditions in the municipality, it was observed that in the urban scope there are areas with abundant vegetation to be preserved, such as the military reserve and private areas. In addition, Cáceres has large empty areas close to the most compromised regions, which can be converted into parks and leisure areas through reforestation.

Considering the low land occupation, it is possible to implement road afforestation programs and also in the centre of the blocks, in order to provide a reduction in the temperature of the local climate, since in the surroundings of the city there are sufficient areas for reforestation and filtering, thus producing air fresh and moist. This is possible mainly in the northern part of the city.

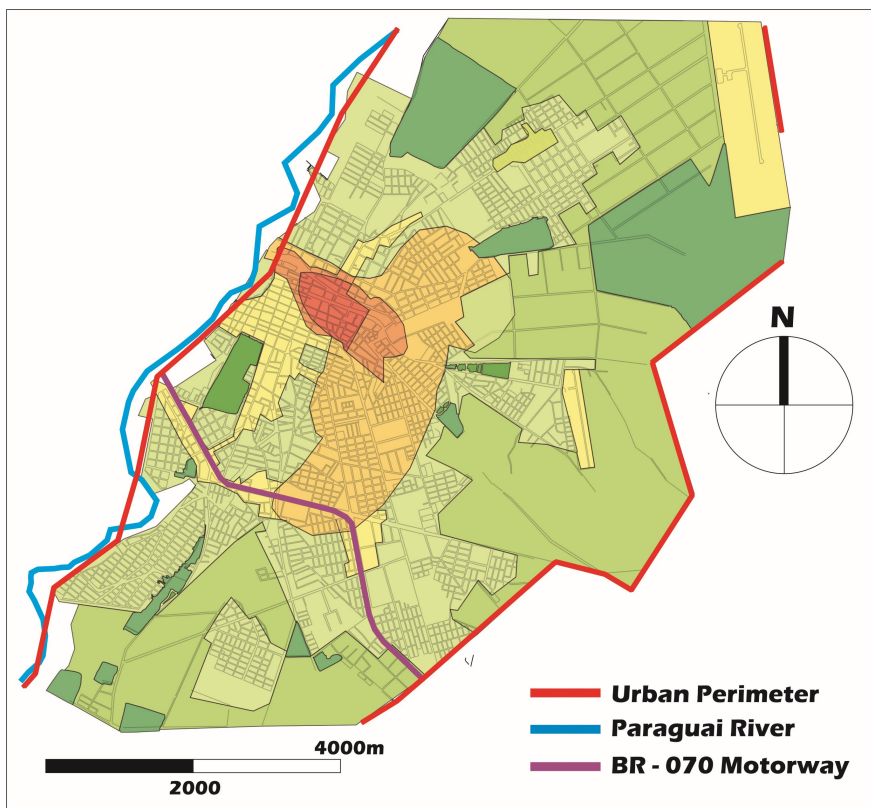

Very low temperature and humidity changes. Large areas of production of fresh and humid air, with air filtration function.

Little changes in temperature and humidity. Significant Production of fresh and moist air.

Some changes in temperature, humidity and wind speed.

Considerable changes in temperature, humidity and wind speed

Strong changes in temperature, humidity and wind speed

Intense increase in temperature and decrease in humidity and wind speed

Maximum changes in climatic elements. Intense increase in temperature and decreased humidity and wind speed.

Fig. 16 Map of Climate Change in Cáceres-MT. (PDMC Prognosis, 2018) 
If no action is taken, there is a tendency for the registered changes to worsen, generating an increase in expenses with electrical energy for air conditioning, in addition to an increase in expenses with public health due to diseases. These climatic changes cause unfavourable effects on human health, such as respiratory diseases, drop in productivity caused by thermal discomfort and discouragement for outdoor activities. In addition, due to poor weather conditions, there is no incentive to use non-motorized means of transport, causing an intense flow of vehicles on the roads.

\section{Proposals}

\section{Urban Perimeter}

Since the expansion area of the urban perimeter is not very occupied, it is necessary to change the Urban Perimeter Law, so that it excludes its current expansion area and that the new subdivisions appear in places that already have urban infrastructure. In this way, the occupation of areas that must be preserved from the environmental point of view is avoided.

In addition, it is recommended to adopt densification measures in the city close to the streets that connect the subdivisions farthest from the Centre. However, this density must be controlled and directed, so that the areas with the best conditions for urbanization and infrastructure are occupied. For this reason, one of the ways to control this density is to create incentives so that areas closer to the centre, and equipped with more infrastructure, are occupied by the population. Once this density is not directed, areas that do not have infrastructure, such as water and electricity supply systems, can be occupied.

Therefore, the creation of new subdivisions should be discouraged until all areas determined for occupation are subdivided, requiring incentives for the occupation of urban voids. This incentive also contributes to the preservation of green areas within the urban perimeter, since these will not be degraded, whether private or public, for the creation of new subdivisions.

\section{Density}

Due to the spread of the urbanized area and the little verticalization found, the population density of the city is very low. Therefore, densification measures are recommended in areas with more services and infrastructure, so it is necessary to induce the structuring of the urbanization process in a compact and rational way, taking advantage of the availability, centrality and potential of land. Density must be adapted to the physical environment and climatic conditions in order to guarantee the quality of the built spaces.

In addition, it is important to encourage the verticalization of more urbanized areas, since there are no geotechnical restrictions, due to the good support conditions of the city's soil. In this way, verticalization increases population density and contributes to the efficiency of infrastructure networks, which can serve more people in smaller spaces. This attitude is feasible if it occurs in areas that already have electricity, basic sanitation and also have easy access to the road system.

Observing the existence of urban voids in areas with good infrastructure and close to the main centralities of the city, it is necessary to create measures to contain the opening of new subdivision areas until these voids are filled. These voids must be filled considering the climatic conditions, such as the prevailing wind directions, solar orientation and availability of natural light, in order to contribute to urban sustainability.

\section{Land use}

It is necessary to organize the use and occupation of land to meet the economic and social functions of the City, making urban development, the road system, environmental conditions, public transportation, basic sanitation and other urban services compatible. In other words, it is necessary to combine the intensification of land occupation with the expansion of the infrastructure capacity to meet current and future demands. Therefore, considering a very diffuse occupation and the concentration of the main businesses in the central part, it is necessary to encourage mixed use in the different regions of the city. New regional centralities should be encouraged, thus favouring the entire urban population and public transport services, since it can reduce the need to travel to the central part of the city, balancing the relationship between places of employment and housing.

In addition, there should be processes for the maintenance and expansion of urban services distributed throughout the regions of the city, such as energy distribution, water supply, waste collection, public lighting, public transportation, public cleaning, among others. Another factor that can contribute to the use and occupation of land is to adopt measures to encourage commercial use on the ground floor in vertical buildings, since it is already present throughout the city, with some regions being more accentuated, others less so. This contributes to centralities being formed in regions far from the center. As an incentive to occupy the land within the urban perimeter, it is necessary to increase the supply of infrastructure for non-motorized and collective transport in the most distant locations of the centre, in addition to encouraging the pedestrian 
circulation system. Therefore, the roads in the municipality must guarantee accessibility for pedestrians, cyclists, public transportation and also for people with special needs. Thus, bike lanes should be implanted in the municipal road network, in order to encourage the use of non-motorized transport. In addition, campaigns to encourage the aforementioned transport should be created, since it contributes to reducing the pollution of gases emitted by motor vehicles.

Another aspect to be considered in order to contribute to the city of Cáceres is to propose the creation of Special Environmental Protection Zones in the marginal areas of the Paraguay River, inserted within the urban perimeter. In the region covered by the Historic Centre, the rules of use and occupation of the margins must obey what the legislation provides, in accordance with the current legislation. In the marginal areas outside the Historic Centre, an Environmental Interest Zone should be created, in order to allow only low-occupancy and leisure activities to be implemented. In this sense, within the urban perimeter, on the banks of the River, only Urban Parks, sports and leisure areas and similar activities would be allowed, which allow the maintenance of large vegetated and permeable areas, from reforestation with native species.

Such measures would be in accordance with the current municipal and state legislation, in addition to providing greater control of floods through larger areas for water infiltration. Another important aspect of these preservation areas is the fact that they provide better climatic conditions throughout the city. Once occupied by sports and leisure equipment, it also has the function of preventing possible irregular occupations on the banks of the River, with environmental damage and risks to the population.

\section{Urban Expansion}

Since the city has been growing radiocentricly, from the original centre, it is necessary to make viable rings from the centre of the city, allowing the interconnection of neighbourhoods without the need to access the central region. Therefore, these rings would seek to guarantee the necessary conditions to exercise the urban function of circularity, through an integrated network of roads, with safety and comfort.

In addition, within the urban expansion process, mechanisms must be established for joint action by the public and private sectors in the city's urban transformations, especially for absorbing impacts generated by large-scale enterprises, as well as for the recovery and maintenance of areas of environmental interest. However, as a way to guarantee the maintenance of low-density occupation in the expansion areas, it becomes necessary, first, to prioritize the occupation of the urban voids found in detriment to the allotment of new plots, until the entire urban area is consolidated.

\section{Environmental changes}

According to the climatic analysis of Cáceres, it was observed that the most affected area is found in the central part of the city (from Praça Barão to Av. 7 de Setembro) due to the high concentration of shops, services and intense traffic of people and vehicles. Thus, it is necessary to implement mitigating measures to control climate change in this region, such as policies for reducing and removing greenhouse gases, reducing the use of non-renewable sources of energy and encouraging sustainable construction, in addition to reducing motorized transport in the most affected areas.

Therefore, measures should be proposed to control the use of motor vehicles in these most compromised areas, such as determining vehicle traffic schedules, where the preference for daytime use is given to pedestrians, cyclists and non-motorized transport, as well as propose the alternative of mixed use of types of transport at different times of the day.

In order to significantly control and prevent the advance of climate change, urban parks can be created with a high amount of vegetated area. Unoccupied areas to the north of the city should be reforested, in order to provide an area for the formation of fresh winds in the direction of the prevailing winds, since in the surroundings of the city there are sufficient areas for reforestation, filtering and production of fresh and humid air.

In the long term, it is necessary to create a system of green areas in the city and its surroundings, in order to guarantee relevant vegetable reserves, since there are large empty areas close to the most compromised regions, which can be converted into parks and leisure areas from reforestation and space qualification.

\section{CNCLUSIONS}

The research proved to be effective regarding the insertion of climate issues in the discussion of urban planning in Cáceres-MT, since through the stages of the Municipal Master Plan, diagnosis, public management, prognosis and proposals there is knowledge that can support the development of bioclimatic guidelines through complementary laws. The methodology for assessing the urban climate of small and medium-sized cities, developed by Sanches (2015), was effective for climate monitoring. In addition, it was possible to analyse the climatic variables over the years and perceive changes in the urban environment, through the 
influence of land use and occupation in the modification of variables, such as air temperature, relative humidity, precipitation, speed and wind direction. It is suggested to continue monitoring the climatic conditions of the city over time and there is also a need for in-depth studies on the behavior of wind flow in the city.

According to the studies of climatic variables carried out in Sinop-MT by Sanches (2015), it was noted that measurements in the dry season represent the most critical period from the climatic point of view throughout the year. Therefore, since the research and delivery of the Master Plan was restricted to one year, measurements in Cáceres-MT were carried out in September only during the dry season. However, in order to complement the data, measurements can be made during the rainy season.

Finally, it was found that the use of maps, clearly allowed the visualization of climate change in the urban perimeter of Cáceres-MT. Thus, it contributed positively to the participation of the population in the process of preparing proposals with measures to mitigate the harmful effect of the climate changes analysed.

\section{REFERENCES}

Akbari, H.; Kolokotsa, D. Three decades of urban heat islands and mitigation technologies. Energy \& Buildings, v. 133, p. 834-842, 2016.

Annunciação, L. Instrumentação, modelagem e validação de procedimento a partir de gradientes de temperatura e umidade relativa. 2016. 88 f. Tese (Doutorado) - Curso de Física Ambiental, Universidade Federal de Mato Grosso Instituto de Física Programa de pós- graduação em Física Ambiental, Cuiabá, 2016.

Assis, E. S. A abordagem do clima urbano e aplicações no planejamento da cidade: reflexões sobre uma trajetória. VIII Encontro Nacional sobre Conforto no Ambiente Construído, p. 92-101, 2005.

Assis, E. S. Estudo integrado da ilha de calor em áreas urbanas e sua contribuição ao planejamento: o caso de Belo Horizonte, MG. Fórum Patrimônio, Belo Horizonte, v.4, n.1, p. 69-83, 2011.

Assis, E. S. Métodos preditivos da Climatologia como subsídios ao planejamento urbano: aplicação em conforto térmico. Terra Livre, v. 1, n.20, p. 145-158, 2003.

Barbirato, G. M.; Souza, L. C. L.; Torres, S. C. Clima e cidade: a abordagem climática como subsídio para estudos urbanos. EDUFAL. Maceió, 2007.

Barbugli, R. A. Influência do ambiente construido na distribuição da temperature do ar em Araraquara/SP. 2004. Dissertação (Mestrado em Construção Civil) - Universidade Federal de São Carlos. 2004.

Cáceres, Prefeitura Municipal. Plano Diretor do município de Cáceres. 2010. Disponível em: < https://sic.tce.mt.gov.br/3/home/download/id/92402>. Acesso em: 05 abril 2018.

Candido, C. R.; Sanches, J. C. M. EVOLUÇÃO DAS VARIÁVEIS MICROCLIMÁTICAS DE SINOP - MT: Estudo comparativo do ano de 2017 com estudos anteriores. 2017. 57 f. TCC (Graduação) - Curso de Engenharia Civil, Universidade do Estado de Mato Grosso, Sinop, 2017.
Duarte, F. Planejamento Urbano. Ibpex. Curitiba, 2011

Fialho, E. S. Ilha de calor em cidade de pequeno porte: um caso de Viçosa, na Zona da Mata Mineira. Tese de doutorado FFLCH/USP. São Paulo, 2009.

Franco, M. A. R. Planejamento ambiental para a cidade sustentável. Annabluma - FAPESPE. São Paulo, 2001.

Gheno, E. L. Uso do solo, microclimas e clima local no bairro cidade alta, Cuiabá-MT. Instituto de Ciências Humanas e Sociais, Programa de Pós-Graduação - Mestrado em Geografia. Cuiabá, p. 79. 2013.

Gomes, P. S.; Lamberts, R.O estudo do clima urbano e a legislação urbanística: considerações a partir do caso Montes Claros, MG. In: Ambiente Construído, v. 9, n. 1, p. 73-91, jan./mar. Porto Alegre, 2009.

Grimmond, C. S. B. et al. Climate and more sustainable cities: Climate information for improved planning and management of cities (Producers/Capabilities Perspective). Procedia Environmental Sciences, v. 1, n. 1, p. 247-274, 2010.

Häb, K.; Ruddell, B. L.; Middel, A. Urban Climate Sensor lag correction for mobile urban microclimate measurements. Urban Climate, v. 14, p. 622-635, 2015.

Ibge. Instituto Brasileiro de Geografia e Estatística, 2017. Disponivel em:

$<$ http://cidades.ibge.gov.br/xtras/perfil.php?codmun=510790 $>$. Acesso em: 05 maio 2018.

Inmet. Instituto Nacional de Meteorologia. 2017. Disponível em: $<$ http://www.inmet.gov.br/portal/index.php?r=estacoes/estacoesA utomaticas $>$. Acesso em: 21 set. 2017.

Instrutemp. Manual de Instruções: Estação meteorológica com display touch screen ITWH-1080, 2010. Available at: $<$ http://instrutemp.provisorio.ws/2010_09/ITWH-1080.pdf> Acesso em: 02 de março 2017.

Krüger, E. L.; Gonzalez, D. E. Impactos da alteração no albedo das superfícies no microclima e nos níveis de conforto térmico de pedestres em cânions urbanos. Ambiente Construído, v. 16, p. 89106, 2016

Lamberts, R., Gomes, P. S., Gomes, F. S. Perspectivas para a Utilização da Climatologia na Avaliação do Ambiente construído visando o Planejamento urbano. Estudo preliminar para Montes Claros/MG. In: COBRAC 2006. Congresso Brasileiro de Cadastro Técnico Multifinalitário. UFSC. Anais. Florianópolis, 2006.

Liu, L.; Liu, J.; Lin, Y. Spatial-Temporal Analysis of the Urban Heat Island of a Subtropical City by Using Mobile Measurement. Procedia Engineering, v. 169, p. 55-63, 2016.

Maitelli, G. T.; ZAMPARONI, C. A. G. P.; LOMBARDO, M. A. Ilha de calor em Cuiabá-MT: uma abordagem de clima urbano. In: $3^{\circ}$ Encontro Nacional de Estudos Sobre o Meio Ambiente. Anais. P. 561-571. Londrina, 1991.

Marques, M. C. Introdução a um estudo prospectivo dos parâmetros de ocupação e parcelamento do solo sob a ótica do conforto higrotérmico para a Zona Residencial - 9, São Luís-MA. Dissertação (Mestrado) - Programa de Pós- Graduação em Arquitetura e Urbanismo da Universidade Federal do Rio de Janeiro - UFRJ. Rio de Janeiro, 2012.

Moreira, M; Macruz, J. C.; Castro, M. J. Plano Diretor: Passo a Passo. São Paulo: Fundação Prefeito Faria Lima - Cepam, 199 p., 2005.

Moreno, G.; Higa, T. C. S. Geografia de Mato Grosso: Território, Sociedade e Ambiente. 296 p. Cuiabá: Entrelinhas, 2005.

Nakata-Osaki, C. M.; Cristina, L.; Souza, L. DE. Impacto da geometria do cânion urbano na intensidade de ilha de calor noturna: análise através de um modelo simplificado adaptado a um SIG. Ambiente Construído, v. 16, p. 73-87, 2016.

Oliveira, A. S. Influência da vegetação arbórea no microclima e uso de praças públicas. Tese (Doutorado) - Programa de 
Pósgraduação em Física Ambiental, Universidade Federal de Mato Grosso. Cuiabá, 2011.

Plano Diretor de Cáceres: Diagnóstico. 2017. Disponível em: $<$ http://www.caceres.mt.gov.br/downloads/dpd.pdf $>$. Acesso em: 20 fev. 2018.

Rabi, A. N. I. Planejamento urbano e o uso eficiente da energia elétrica: plano diretor, perímetro urbano, uso do solo, parcelamento. IBAM/DUMA. Rio de Janeiro: 1999.

Romero, M. A. B. Arquitetura do lugar: uma visão bioclimática da sustentabilidade em Brasília. 1. Ed. Nova Técnica Editorial. São Paulo, 2011.

Sanches, J. C. M. Uma metodologia para a inserção do clima como critério para o planejamento urbano: análise da cidade de SinopMT. 2015. Tese (Doutorado em Urbanismo) - Universidade Federal do Rio de Janeiro, Rio de Janeiro.

Sanches, J. C. M.; Candido, C. R.; Ohira, S. Clima Urbano como critério de planejamento de assentamentos de habitações de interesse social: o caso de Sinop-MT, na Amazônia Legal brasileira. 4o CIHEL - Congresso Internacional da Habitação no Espaço Lusófono, n. d, 2017.

Santos, L.; Zamparoni, C. A. G. P.; Soares, J.C.de O. O ritmo pluviométrico na região de Cáceres-MT no período compreendido entre a série histórica de 1971 A 2010. Revista Geonorte, v. 1, n. 5, p.1091-1102, 2012.

Sette, D. M. O Clima Urbano de Rondonópolis - MT. Dissertação (Mestrado em Geografia). São Paulo, 1996. Universidade de São Paulo, USP, 1996.

Siqueira, G. M. et al. Zoneamento de Parâmetros Climáticos no Estado de São Paulo (Brasil) Utilizando Técnicas de Geoestatística. Revista Brasileira de Geografia Física, v. 3, p. 612-629, 2012.

Souza, J. R. G.; Assis, E. S. Ajuste de dados representativos de temperatura em medições móveis em áreas urbanas. In: IX
Encontro Nacional e V Encontro Latino- Americano de Conforto no Ambiente Construído, Ouro Preto. Anais do IX Encontro Nacional e V Encontro Latino-Americano de Conforto no Ambiente Construído. V. 1. p. 1749-1758 . ANTAC/UFMG. São Paulo, 2007.

Trindade, T. Q.; Sanches, J. C. M. Análise vetorial da dinâmica dos ventos na cidade de Sinop-MT: projeto piloto. 2016. Trabalho de Conclusão de Curso. Universidade do Estado de Mato Grosso. Sinop - MT.

Vendramini, W. J.; AL., Et.. Análise espacial do crescimento urbano de Cáceres/MT, Pantanal mato-grossense. $6^{\circ}$ Simpósio de Geotecnologias no Pantanal: Embrapa Informática Agropecuária/INPE, Cuiabá, p.729-737, 22 out. 2016.

Weber, D. D.; Englund, E. J. Evaluation and Comparison of Spatial. Mathematical Geology, v. 26, n. 5, p. 589-603, 1994.

Wilheim, J. O sustantivo e o adjetivo. São Paulo: Perspectiva, 1979.

Zamparoni, C. A. G. P. Ilha de calor em Barra do Bugres e Tangará da Serra - MT: uma contribuição ao estudo de clima urbano em cidades de pequeno porte em área tropical. Dissertação (Mestrado em Geografia). São Paulo, FFLCH - USP, 1995. Faculdade de Filosofia, Letras e Ciência Humanas, Universidade de São Paulo, 1995.

Zárate, L. E; Gonçalves, W. B; Assis, E. S; Dias, S. M. Estimativa de dados climáticos utilizando redes neurais artificiais para fins de zoneamento bioclimático do estado de Minas Gerais. XII Encontro Nacional de Tecnologia do Ambiente Construído, n. 1, 2008.

Yamamoto, J. K. Geoestatística: Conceitos + aplicações. São Paulo: Oficina de Textos, 2013. 